JURNAL KETAHANAN NASIONAL

P-ISSN: 0853-9340, e-ISSN: 2527-9688

Online sejak 28 Desember 2015 di: http://jurnal.ugm.ac.id/JKN

VOLUME 22

No. 2, 25 Agustus 2016

Halaman 180-198

\title{
PERAN ORGANISASI KEPEMUDAAN DALAM MEMBANGUN KARAKTER PEMUDA DAN IMPLIKASINYA TERHADAP KETAHANAN PRIBADI PEMUDA (Studi Pada Pimpinan Cabang Gerakan Pemuda Ansor di Kabupaten Sukoharjo Provinsi Jawa Tengah)
}

\author{
Pipit Widiatmaka \\ Pusat Studi Demokrasi dan Ketahanan Nasional Universitas Sebelas Maret \\ pipit.widiatmaka.pkn@gmail.com
}

Agus Pramusinto

Fakultas Ilmu Sosial dan Politik Universitas Gadjah Mada

Kodiran

Fakultas Ilmu Budaya Universitas Gadjah Mada

\begin{abstract}
This research discussed about the role of the Branch Leader of Ansor Youth Movement in Sukoharjo Regency in building youth character and its implications towards youth personal resilience.

This research used descriptive qualitative method. There were 5 (five) data collecting techniques used, such as deep interview, observation, literature study, internet, and documentation. The data analyzing process used in this research were collecting data, reducing data, presenting data, and drawing conclusion.

The result of this research showed that the role of the Branch Leader of Ansor Youth Movement in Sukoharjo Regency could build youth character, but could not be maximized because there were several obstacles, namely financial condition, the lack of the management coordination, the lack of the management activeness, position vacuity, and personal interest. The character which could be built in that organization were religious, responsible, discipline, independence, honesty, mandatory, empathy, cooperative, confidence, creativity, toughness, leadership, tolerance, and nationalism. The role of the Branch Leader of Ansor Youth Movement in Sukoharjo Regency could implicate in youth personal resilience of the young, especially in Basic Education and Training, because other activities didn't work effectively. The implication of Basic Education and Training were that it could build several characters, such as independence, togetherness, confidence, heading towards ideology, dynamics, creativity, and toughness.
\end{abstract}

Keywords: Youth Organization, Youth Character, Youth Personal Resilience.

\begin{abstract}
ABSTRAK
Penelitian ini membahas tentang peran Pimpinan Cabang Gerakan Pemuda Ansor di Kabupaten Sukoharjo dalam membangun karkater pemuda dan implikasinya terhadap ketahanan pribadi pemuda

Penelitian ini menggunakan metode deskriptif kualitatif. Teknik pengumpulan data menggunakan 5 (lima) teknik, yaitu wawancara mendalam, observasi, studi pustaka, internet, dan studi pustaka. Proses analisis data dalam penelitian ini, yaitu pengumpulan data, reduksi data, penyajian data, dan penarikan kesimpulan.
\end{abstract}


Pipit Widiatmaka, Agus Pramusinto, dan Kodiran -- Peran Organisasi Kepemudaan Dalam Membangun Karakter Pemuda Dan Implikasinya Terhadap Ketahanan Pribadi Pemuda (Studi Pada Pimpinan Cabang Gerakan Pemuda Ansor Di Kabupaten Sukoharjo Provinsi Jawa Tengah)

Hasil penelitian di lapangan menunjukkan bahwa peran Pimpinan Cabang Gerakan Pemuda Ansor di Kabupaten Sukoharjo dapat membangun karakter pemuda, namun belum bisa maksimal karena terdapat beberapa kendala, yaitu keuangan, koordinasi pengurus masih kurang, keaktifan pengurus masih kurang, terjadi kekosongan jabatan, dan kepentingan pribadi. Karakter yang dapat dibangun di organisasi tersebut, yaitu religius, tanggung jawab, disiplin, mandiri, kejujuran, amanah, peduli antar sesama, kerja sama, percaya diri, kreatif, pantang menyerah, kepemimpinan, toleransi, dan nasionalisme. Peran Pimpinan Cabang Gerakan Pemuda Ansor di Kabupaten Sukoharjo dapat berimplikasi terhadap ketahanan pribadi pemuda khususnya Pendidikan dan Latihan Dasar (Diklatsar), karena kegiatan yang lain tidak berjalan dengan efektif. Implikasi dari Pendidikan dan Latihan Dasar (Diklatsar) dapat membangun kepribadian yang mandiri, kebersamaan, percaya diri, berpegang teguh pada prinsip, dinamis, kreatif dan pantang menyerah.

\section{Kata Kunci: Organisasi Kepemudaan, Karakter Pemuda, Ketahanan Pribadi Pemuda}

\section{PENGANTAR}

Pembangunan pemuda menjadi program penting bagi setiap negara di dunia, karena pemuda merupakan aset terbesar bangsa sekaligus tumpuan harapan yang akan menegakkan kembali cita-cita bangsa, selain itu pemuda juga merupakan bagian dari roda perputaran zaman yang diharapkan kembali dapat menjadi agent of change (Dewanta dan Syaifullah, 2008: 46). Peran dan partisipasi pemuda sangat penting dalam membangun kesejahteraan masyarakat, sehingga tidak dapat dipungkiri bahwa setiap negara selalu berusaha untuk membangun pengetahuan, keterampilan, dan karakter pemuda. Ada peribahasa yang mengungkapkan bahwa barang siapa menguasai pemuda, maka akan menguasai masa depan (Tilaar, 1991: 34). Pada dasarnya pemuda memiliki peran yang sentral untuk kemajuan bangsa Indonesia.

Peran dan partisipasi pemuda saat ini belum menunjukkan hasil yang maksimal, apabila dibandingkan dengan pemuda di era pra dan pasca kemerdekaan. Astuti (2010: 41) mengungkapkan bahwa pemuda saat ini sedang menggalami krisis karakter yang memprihatinkan. Imam Nahrowi (Menteri Pemuda dan Olahraga) ketika memberi sambutan pembukaan Konferensi Asia-Afrika juga mengungkapkan bahwa pola perilaku pemuda saat ini sedang menggalami krisis karakter, sehingga akan mengakibatkan gagalnya estafet kepemimpinan bangsa dan semangat kepemimpinan hanya menguntungkan segelintir orang yang berfikir tentang hegemoni dan kapitalisme (Cahyono, 27 April 2015: joglosemar.com).

Data dari Badan Narkotika Nasional (BNN) menunjukkan bahwa pengguna narkoba Indonesia hingga Oktober 2014 jumlahnya semakin meningkat, pasalnya kurang lebih 4 juta warga Indonesia positif sebagai pengguna narkoba. Penggunanya mayoritas adalah pemuda, dari 4 juta orang yang positif menggunakan narkoba, $60 \%$ berada dalam usia 17-27 tahun (Dradjad, 24 Februari 2015: http://kriminalitas.com). Tindakan kriminal lain juga dilakukan oleh segerombolan pemuda yang terdiri dari 10 orang yang menembak seorang anggota polisi di Desa Madegondo, Kecamatan Grogol, Kabupaten Sukoharjo pada pukul 02.15 WIB. Peristiwa tersebut terjadi ketika segerombolan pemuda yang sedang nongkrong di pinggir jalan dibubarkan oleh dua anggota polisi yang sedang patroli, namun segerombolan pemuda tersebut marah. Salah satu dari segerombolan pemuda tersebut ternyata membawa senapan, 
sehingga menembak salah satu dari polisi yang sedang melakukan patroli (Wibowo, 25 Januari 2015: http://joglosemar.com).

Kasus kriminal lain juga dilakukan oleh pemuda di Jl. Ahmad Yani Kecamatan Kartosuro, Kabupaten Sukoharjo. Tiga orang pemuda menganiaya seorang pria yang tidak dikenal identitasnya hingga meninggal dunia. Korban setelah dianiaya oleh pelaku, dibuang ke halte bus yang terletak di seberang jalan. Beberapa hari kemudian polisi menemukan mayat korban tersebut dan langsung melakukan penyidikan. Satu tersangka dari tiga pelaku sudah tertangkap, namun dua pelaku masih menjadi buronan Polres Kabupaten Sukoharjo (Kholil,31 Oktober 2014: http://m.nasional. rimanews.com/).

Peran organsiasi kepemudaan saat ini juga sedang mengalami kemerosotan khususnya dalam membangun karakter pemuda, sehingga tidak dapat dipungkiri banyak pemuda Indonesia yang melakukan tindakan kriminal, selain itu juga akan berdampak pada masa depan bangsa Indonesia mendatang. Irwan Prayitno mengungkapkan bahwa banyak organisasi kepemudaan yang "hidup segan mati pun tak mau" karena kegiatannya tidak berjalan (Ridho, 14 April 2015: http://www.sumbarpost.com).

Gerakan Pemuda Ansor merupakan salah satu organisasi kepemudaan yang perannya dalam membangun karkater pemuda semakin lemah, hal itu karena organisasi tersebut memiliki permasalahan internal. Sifat keorganisasian yang melekat di tubuh Gerakan Pemuda Ansor yang mengemban urusan kepemudaan, keagamaan, kebangsaan, dan kerakyatan, menggambarkan bahwa permasalahan yang dihadapi organisasi tersebut sangat komplek. Fuad (2010: 119-
120) mengungkapkan bahwa persoalan yang dapat dicermati secara kritis yang merupakan masalah kepemudaan yang secara langsung menjadi bagian dari permasalahan di Gerakan Pemuda Ansor, yaitu (1). Lemahnya koordinasi dan konsolidasi secara utuh antara pusat dan daerah hingga tingkat kecamatan, sehingga berdampak pada terbengkalainya berbagai program dan munculnya kader karbitan serta kepemimpinan yang kurang mengakar. (2). Organisasi terlalu padat dengan aktivitas formal dan seremonial seperti kongres, kobes, mubes, rapat, dan muktamar, yang lebih banyak menguras tenaga dan menghabiskan anggaran. (3). Peran organisasi menjadi dilematis kerakyatan yang harus diperjuangkan dengan keberpihakan pada kekuasaan yang lebih dianggap menguntungkan. Hal ini sering membuat organisasi tergoda pada kepentingan sesaat atau justru menjadi alat legitimasi kekuasaan yang bersebrangan dengan kepentingan kerakyatan.

Fenomena tersebut menjadi pesoalan Gerakan Pemuda Ansor karena perannya dalam membangun karakter pemuda menjadi melemah dan kurang serius dalam menyelesaikan permasalahan kepemudaan saat ini, sehingga persoalan kepemudaan di Indonesia semakin kompleks. Krisisnya karakter pemuda akan berimplikasi pada ketahanan pribadi pemuda sehingga pemuda tidak memiliki kepercayaan diri, memegang prinsip, kemandirian, kreativitas, tanggung jawab dan lain sebagainya, yang akan mempengaruhi ketahanan nasional.

Pimpinan Pusat Gerakan Pemuda Ansor pada tanggal 16 Juli 2012 mengadakan peringatan hari lahir ke-78 di Solo dengan mengusung tema memperkokoh kebhinekaan dan mengentaskan kemiskinan. Yaqul Cholil 
Pipit Widiatmaka, Agus Pramusinto, dan Kodiran -- Peran Organisasi Kepemudaan Dalam Membangun Karakter Pemuda Dan Implikasinya Terhadap Ketahanan Pribadi Pemuda (Studi Pada Pimpinan Cabang Gerakan Pemuda Ansor Di Kabupaten Sukoharjo Provinsi Jawa Tengah)

selaku ketua panitia mengungkapkan peringatan hari lahir Gerakan Pemuda Ansor dilaksanakan di Solo, karena peran Gerakan Pemuda Ansor di Solo Raya (Solo, Karanganyar, Wonogiri, Boyolali, Sragen, dan Sukoharjo) masih sangat lemah apabila dibandingkan dengan daerah lainnya, terutama dalam kaderisasi pemuda (Primartantyo, 13 Juli 2012: tempo.com). Lemahnya kaderisasi di organisasi tersebut merupakan permasalahan yang berimplikasi pada karakter pemuda yang semakin jauh dari nilai-nilai Pancasila, sehingga banyak terjadi tindakan kriminal yang dilakukan oleh pemuda terutama di Kabupaten Sukoharjo.

Penelitian ini didasarkan atas beberapa teori yang secara lengkap diuraikan di bawah ini.

Peran (role) adalah proses dinamis kedudukan (status), apabila aktor melakukan hak dan kewajiban sesuai dengan kedudukannya, maka orang tersebut menjalankan suatu peran (Soekanto, 2009: 212-213). Membangun karkater pemuda yang dilakukan organisasi kepemudaan merupakan salah satu peran yang dilakukan oleh organisasi kepemudaan. Undang-Undang Nomor 20 Tahun 2009 tentang Kepemudaan pada Pasal 43 menjelaskan bahwa organisasi kepemudaan harus memiliki keanggotaan, kepengurusan, tata laksana kesekretariatan dan keuangan, serta anggaran dasar dan anggaran rumah tangga. Pada Pasal 1 ayat (1) juga menjelaskan bahwa pemuda adalah warga negara Indonesia yang memasuki periode penting pertumbuhan dan perkembangan yang berusia 16 (enam belas) sampai 30 (tiga puluh) tahun. Pembangunan karakter pemuda melalui organisasi pada dasarnya sangat efektif, apabila seluruh rangkaian kegiatannya dapat berjalan dengan maksimal.
Suyadi (2013: 5-6) mengungkapkan karakter merupakan nilai-nilai universal perilaku manusia yang meliputi seluruh aktivitas kehidupan, baik yang berhubungan dengan Tuhan, diri sendiri, sesama manusia maupun dengan lingkungan yang terwujud dalam pikiran, sikap, perasaan, perkataan, dan perbuatan yang berdasarkan norma-norma agama, hukum, tata krama, budaya, dan adat istiadat. Ambarita (2013: 3) menjelaskan bahwa membangun karakter (character building) generasi muda merupakan upaya untuk membangun bangsa, sehingga karakter pemuda yang harus dibangun, yaitu (1) rasa cinta pada Tuhan dan kebenaran, (2) tanggung jawab, disiplin, dan mandiri, (3) amanah dan kejujuran, (4) rasa hormat dan sopan santun, (5) kasih sayang, peduli dan kerja sama, (6) percaya diri, kreatif, dan pantang menyerah, (7) adil dan kepemimpinan, (8) rendah hati, dan (9) toleransi, cinta tanah air, dan cinta damai.

Pendidikan karakter merupakan solusi untuk mengatasi permasalahan krisis karakter pemuda yang dialami Indonesia saat ini, sehingga tidak dipungkiri setiap jalur pendidikan formal, nonformal, dan informal mengimplementasikan pendidikan karakter. Majid dan Andayani (2012: 112-113) menjelaskan strategi pendidikan karakter yang efektif untuk membangun akhlak mulia, terdiri dari tiga tahap yaitu moral knowing/learning to know, moral loving/moral feeling, dan moral doing/learning to do.

Karakter sangat penting untuk dibangun karena secara langsung maupun tidak langsung akan berimplikasi pada ketahanan pribadi. Soedarsono (1997: 53-54) menjelaskan ketahanan pribadi merupakan turunan dari ketahanan nasional, yang berawal dari tingkat 
nasional kemudian turun ke dalam diri pribadi setiap individu. Ketahanan pribadi yang perlu ditumbuh-kembangkan dan harus dapat mencerminkan sosok manusia Indonesia yang berkepribadian Pancasila memiliki ciriciri, yaitu (1) memiliki rasa percaya diri dan berpegang pada prinsip, (2) memiliki jiwa dinamis, kreatif dan pantang menyerah, dan (3) memiliki kemandirian dan mendambakan kebersamaan.

Secara spesifik permasalahan yang diangkat dalam penelitian ini, ialah (1) peran Pimpinan Cabang Gerakan Pemuda Ansor di Kabupaten Sukoharjo dalam membangun karakter pemuda, dan (2) implikasi peran Pimpinan Cabang Gerakan Pemuda Ansor di Kabupaten Sukoharjo terhadap ketahanan pribadi pemuda. Metode penelitian menggunakan pendekatan kualitatif yang bersifat deskriptif analisis. Pimpinan Cabang Gerakan Pemuda Ansor di Kabupaten Sukoharjo menjadi lokasi penelitian karena perannya dalam membangun karakter masih tergolong masih lemah apabila dibandingkan dengan daerah yang lain.

Jenis penelitian yang digunakan dalam penelitian ini adalah penelitian kualitatif dan menggunakan metode penelitian deskriptif. Obyek yang diteliti adalah organisasi kepemudaan Pimpinan Cabang Gerakan Pemuda Ansor di Kabupaten Sukoharjo. Teknik pengumpulan data menggunakan beberapa teknik, yaitu (1) wawancara, yang bersifat mendalam (in-depth interview) dan informan berjumlah 17 (tujuh belas) orang, (2) observasi, teknik yang digunakan ialah observasi berperan dan obyek yang diamati ialah place, actor, dan activity, (3) studi pustaka, yang terdiri dari buku dan jurnal yang terkait, (4) internet, yang berupa berita yang terkait dengan penelitian ini, dan (5) dokumentasi, yang berupa foto wawancara dan kegiatan di organisasi kepemudaan Pimpinan Cabang Gerakan Pemuda Ansor di Kabupaten Sukoharjo . Penelitian ini menggunakan teknik analisis data interaktif yang terdiri dari 4 tahap, yaitu (1) pengumpulan data, (2) reduksi data, (3) penyajian data, dan (4) penarikan kesimpulan.

\section{PEMBAHASAN}

\section{Peran Pimpinan Cabang Gerakan Pemuda Ansor dalam Membangun Karakter}

Peran Pimpinan Cabang Gerakan Pemuda Ansor dalam membangun karakter dapat dijelaskan di bawah ini.

Pertama, Rijalul Ansor. Kegiatan Majelis Dzikir dan sholawat Rijalul Ansor merupakan sarana pemuda untuk menuntut ilmu keagamaan, penguatan aqidah Ahlussunnah Wal Jama'ah dan dakwah Islam rahmatan lil a'lamin (rahmat untuk alam semesta). Berdasarkan Peraturan Organisasi Gerakan Pemuda Ansor tentang Majelis Dzikir dan Sholawat Rijalul Ansor pada Pasal 2 dijelaskan bahwa Majelis Dzikir dan Sholawat Rijalul Ansor dibentuk mulai dari Pimpinan Pusat, Pimpinan Wilayah, Pimpinan Cabang, Pimpinan Anak Cabang dan Pimpinan Ranting di seluruh Indonesia. Majelis Dzikir dan Sholawat Rijalul Ansor bersifat semi otonom di setiap tingkatan yang diangkat, disahkan dan diberhentikan oleh pimpinan Gerakan Pemuda Ansor di masing-masing tingkat kepengurusan.

Rijalul Ansor merupakan kegiatan pengajian yang di dalamnya terdapat proses pendidikan karakter dengan menggunakan metode pembelajaran ceramah dan tanya jawab. Seorang ustadz memberi nasehat 
Pipit Widiatmaka, Agus Pramusinto, dan Kodiran -- Peran Organisasi Kepemudaan Dalam Membangun Karakter Pemuda Dan Implikasinya Terhadap Ketahanan Pribadi Pemuda (Studi Pada Pimpinan Cabang Gerakan Pemuda Ansor Di Kabupaten Sukoharjo Provinsi Jawa Tengah)

kepada para jama'ah, kemudian dilanjutkan dengan tanya jawab (diskusi), sehingga proses pendidikan karakter dapat berjalan dengan efektif. Rijalul Ansor di Pimpinan Cabang Gerakan Pemuda Ansor di Kabupaten Sukoharjo berjalan secara rutin setiap 35 sekali setiap minggu legi.

Pada hari minggu legi tanggal 13 Desember 2015 ternyata kegiatan Rijalul Ansor di Pimpinan Cabang Gerakan Pemuda Ansor di Kabupaten Sukoharjo tidak dilaksanakan, karena pada tanggal tersebut mendekati Pilkada di Kabupaten Sukoharjo dan banyak pengurus yang menjadi panitia pemilu, sehingga diliburkan. Pada hari minggu legi selanjutnya tanggal 17 Januari 2016 menunjukkan bahwa kegiatan Rijalul Ansor juga tidak dilaksanakan, karena wakil ketua yang membidangi Rijalul Ansor di Pimpinan Cabang Gerakan Pemuda Ansor di Kabupaten Sukoharjo terjadi kekosongan jabatan. Orang yang menjabat di posisi tersebut, sudah pindah dan bekerja di Cirebon. Ketua Pimpinan Cabang Gerakan Pemuda Ansor di Kabupaten Sukoharjo hingga saat ini belum mengambil sikap dan tindakan untuk mengganti jabatan yang ditinggal oleh Sigit Santoso tersebut.

Kepemimpinan Nuril Huda periode tahun 2013-2017 merupakan kepemimpinan yang belum bisa melanjutkan kegiatan Rijalul Ansor yang sebelumnya berjalan secara rutin setiap malam minggu legi (kepemimpinan Khomsun Nur Arif tahun 2009-2013), sehingga proses pembangunan karakter menjadi terkendala dan berdampak pada minimnya kader yang berkarakter. Berdasarkan program kerja periode 2013-2017 Pimpinan Cabang Gerakan Pemuda Ansor di Kabupaten Sukoharjo periode tahun 2013-2017 yang diperoleh dari ketua organisasi tersebut, tidak tertulis kegiatan Rijalul Ansor, padahal di dalam Peraturan Organisasi Gerakan Pemuda Ansor tentang Rijalul Ansor, di setiap Pimpinan Cabang harus melaksanakan kegiatan Rijalul Ansor. Hal ini berdampak pada minimnya kader di Pimpinan Cabang Gerakan Pemuda Ansor di Kabupaten Sukoharjo yang memiliki karakter religius.

Kedua, Pendidikan Kepemimpinan Dasar (PKD). Pendidikan Kepemimpinan Dasar (PKD) merupakan salah satu pendidikan kader yang memiliki fungsi untuk membangun kader yang berkarakter dan militan. Peraturan Organisasi Gerakan Pemuda Ansor Pasal 8 menjelaskan bahwa pendidikan kader adalah usaha sadar dan kegiatan terencana untuk meningkatkan militansi, kualitas dan potensi kader dengan menanamkan ideologi, membentuk dan memperkuat karakter, membangun nilai dan akhlaqul karimah, meningkatkan kapasitas keorganisasian, menguatkan kepedulian dan daya kritis, serta memperkuat kapasitas kepemimpinan untuk mewujudkan kemaslahatan publik dalam kehidupan masyarakat dan berbangsa.

Pelaksanaan Pendidikan Kepemimpinan Dasar (PKD) di Pimpinan Cabang Gerakan Pemuda Ansor di Kabupaten Sukoharjo selama ini belum terjadwal dengan baik, karena wakil ketua bidang kaderisasi yang menjalankan tugas kaderisasi tidak mengetahui program kerja ke depan, sehingga pengkaderan di organisasi tersebut menjadi terkendala. Di sisi lain, wakil ketua Pimpinan Cabang Gerakan Pemuda Ansor di Kabupaten Sukoharjo kurang aktif dalam menjalankan tugas dan fungsinya, sehingga proses kaderisasi di organisasi tersebut menjadi terkendala, selain itu proses pendidikan karakter di organisasi tersebut menjadi tidak efektif karena Rijalul 
Ansor dan Pendidikan Kepemimpinan Dasar (PKD) tidak berjalan sebagaimana mestinya, sehingga tidak dapat dipungkiri organisasi tersebut sangat jarang ditemui kader yang berkarakter dan berkualitas.

Berdasarkan program kerja Pimpinan Cabang Gerakan Pemuda Ansor di Kabupaten Sukoharjo periode tahun 2013-2017, kegiatan Pendidikan Kepemimpinan Dasar (PKD) hanya dilaksanakan satu kali dalam satu periode (tahun 2013-2017), sedangkan amanat Peraturan Organisasi tentang Sistem Kaderisasi Gerakan Pemuda Ansor Pasal 13 ayat (3d) menjelaskan bahwa dalam satu tahun kepengurusan Pimpinan Cabang harus mengadakan minimal 2 (dua) kali Pendidikan Kepemimpinan Dasar (PKD). Hal ini menunjukkan Pimpinan Cabang Gerakan Pemuda Ansor di Kabupaten Sukoharjo melanggar amanat Peraturan Organisasi tersebut, selain itu juga akan mempengaruhi proses pendidikan karakter karena kegiatan tersebut hanya dilaksanakan satu kali dalam 4 (empat) tahun, padahal pendidikan karakter yang efektif adalah berkelanjutan.

Ketiga, Pendidikan dan Latihan Dasar (Diklatsar). Pendidikan dan Latihan Dasar (Diklatsar) merupakan suatu kegiatan yang diadakan oleh Gerakan Pemuda Ansor di setiap Pimpinan Anak Cabang dan Pimpinan Cabang untuk mencetak kader inti yang profesional. Out put dari Pendidikan dan Latihan Dasar (Diklatsar) adalah menjadi Banser (Barisan Ansor Serbaguna) yang merupakan lembaga semi otonom dari Gerakan Pemuda Ansor. Peraturan Organisasi tentang Barisan Ansor Serbaguna (Banser) Pasal 1 menjelaskan Banser (Barisan Ansor Serbaguna) adalah tenaga inti Gerakan Pemuda Ansor sebagai kader penggerak, pengemban dan pengaman program-program sosial kemasyarakatan Gerakan Pemuda Ansor. Pendidikan dan Latihan Dasar (Diklatsar) bersifat semi militer, sehingga melalui kegiatan tersebut dapat mencetak kader yang memiliki kedisiplinan, tanggung jawab, jiwa kepemimpinan, jiwa kebersamaan, kejujuran, kerjasama, patriotisme dan nasionalisme.

Pendidikan dan Latihan Dasar (Diklatsar) berusaha untuk mencetak kader yang profesional yang memiliki karakter disiplin, mandiri, tanggung jawab dan jiwa gotong royong, sehingga apabila anggota yang ingin menjadi kader inti atau Banser (Barisan Ansor Serbaguna) harus memiliki sertifikat kelulusan Pendidikan dan Latihan Dasar (Diklatsar). Materi di dalam Pendidikan dan Latihan Dasar (Diklatsar) terdiri dari teori dan praktik, sehingga tidak hanya membangun pemuda yang ahli dalam teori saja, namun juga membangun kader yang memiliki keterampilan dan karakter.

Partisipasi pemuda selama ini masih sangat kurang dalam mengikuti Pendidikan dan Latihan Dasar (Diklatsar), menggingat Banser (Barisan Ansor Serbaguna) tidak mendapatkan gaji. Kegiatan ini pada dasarnya terbuka untuk seluruh pemuda, meskipun belum pernah menjadi anggota Gerakan Pemuda Ansor. Kegiatan tersebut juga diperuntukan bagi seluruh pemuda yang memiliki minat untuk mengikuti Pendidikan dan Latihan Dasar (Diklatsar).

Pimpinan Cabang Gerakan Pemuda Ansor di Kabupaten Sukoharjo belum mampu melaksanakan Pendidikan dan Latihan Dasar (Diklatsar) karena partisipasi beberapa pengurus masih sangat kurang, sehingga kegiatan ini dilimpahkan ke Pimpinan Anak Cabang Gerakan Pemuda Ansor di Kecamatan 
Pipit Widiatmaka, Agus Pramusinto, dan Kodiran -- Peran Organisasi Kepemudaan Dalam Membangun Karakter Pemuda Dan Implikasinya Terhadap Ketahanan Pribadi Pemuda (Studi Pada Pimpinan Cabang Gerakan Pemuda Ansor Di Kabupaten Sukoharjo Provinsi Jawa Tengah)

Polokarto. Pendidikan dan Latihan Dasar (Diklatsar) dilaksanakan pada tanggal 2931 Januari 2016 dengan mengusung tema "Aktualisasi fungsi, peran serta tanggung jawab kader Banser sebagai Warga NKRI bagi terwujudnya tatanan kehidupan berbangsa dan bernegara". Peserta yang mengikuti Pendidikan dan Latihan Dasar (DIklatsar) sejumlah 75 peserta, yang berasal dari beberapa Kecamatan di Kabupaten Sukoharjo. Di dalam kegiatan tersebut sebagian besar diikuti oleh pemuda yang berumur antara 16 tahun hingga 30 tahun dan juga ada beberapa peserta yang berumur lebih dari 40 tahun.

Jadwal dalam kegiatan tersebut sangat padat meskipun hanya tiga hari, sehingga membutuhkan stamina dan tenaga yang kuat. Peserta agar bisa lulus di Pendidikan dan Latihan Dasar (Diklatsar) dan bisa menjadi kader inti/Banser (Barisan Ansor Serbaguna) harus mengikuti seluruh rangkaian kegiatan, apabila ada peserta yang tidak lulus harus mengikuti Pendidikan dan Latihan Dasar (Diklatsar) selanjutnya.

Materi dalam Pendidikan dan Latihan Dasar (Diklatsar) terbagi menjadi dua, yaitu materi ruangan (teori) dan materi lapangan (praktik). Penjelasan materi ruangan dan lapangan, sebagai berikut:

(1). Materi Ruangan, yang terdiri dari (a). Ke-Nahdlatul Ulama-an. Nahdlatul Ulama yang didirikan oleh K.H Hasyim Asy'ary memegang teguh ajaran Ahlussunnah Wal Jama'ah dan nilai-nilai Pancasila, dengan ajaran tersebut Gerakan Pemuda Ansor yang merupakan badan otonom dari Nahdlatul Ulama diharapkan tidak terpengaruh dengan paham-paham ekstrim yang berkembang saat ini, seperti ISIS. (b). Ahlussunnah Wal Jama'ah. Ahlussunnah Wal Jama'ah merupakan golongan pengikut setia ajaran Islam yang murni sebagaimana yang diajarkan oleh nabi Muhammad SAW beserta para sahabatnya. Di zaman nabi Muhammad SAW umat Islam tidak pernah terjadi perdebatan tentang ajaran Islam yang benar karena semua masalah dapat ditanyakan langsung kepada nabi Muhammad SAW, namun ketika nabi dan para sahabat wafat terjadilah banyak perdebatan mengenai ajaran Islam yang benar. Berdasarkan hadits yang diriwayatkan oleh Imam Thabrani umat yang akan selamat adalah umat yang memegang teguh ajaran Ahlussunnah Wal Jama'ah. (c). Ke-Ansoran. Materi yang disampaikan tentang sejarah perjuangan Gerakan Pemuda Ansor dalam memperjuangkan kemerdekaan Republik Indonesia dan perjuangan fisik melawan PKI ketika peristiwa G30S/PKI. Tujuan materi tersebut disampaikan agar pemuda memiliki karakter patriotisme dan nasionalisme. Pemateri juga menekankan kepada peserta untuk menjadi kader Gerakan Pemuda Ansor yang memiliki karakter religius yang berdasarkan ajaran Ahlussunnah Wal Jama'ah. (d). Manajemen pengamanan dan intelijen dasar. Intelijen Gerakan Pemuda Ansor harus mampu menjaga rahasia, selain itu intelijen memiliki tugas untuk mengumpulkan informasi yang dibutuhkan, kemudian menganalisis informasi yang telah didapatkan, apakah informasi tersebut benar atau tidak. (e). Peraturan dan pengaturan lalu lintas. Anggota Banser (Barisan Ansor Serbaguna) harus memiliki kemampuan mengatur lalu lintas, karena hal tersebut merupakan salah satu tugas utamanya. Pemateri menjelaskan peraturan lalu lintas yang tercantum di dalam Undang-Undang No. 22 Tahun 2009 tentang Peraturan Lalu Lintas dan Angkutan Jalan 
dan memberi pelatihan cara mengatur lalu lintas yang benar. (f). Pendidikan bela Negara. Setiap warga negara memiliki kewajiban untuk membela negaranya, bela negara tidak berarti menggangkat senjata kemudian berperang melawan penjajah atau musuh, namun yang dimaksud bela negara di sini mengisi kegiatan yang bermanfaat bagi diri sendiri, masyarakat, bangsa dan negara, misal Gerakan Pemuda Ansor mengadakan Pendidikan dan Latihan Dasar (Diklatsar) merupakan salah satu wujud bela negara. (g). Peran Pemuda Ansor dalam menjaga Nahdlatul Ulama. Gerakan Pemuda Ansor merupakan kader yang jarus dapat mengawal para ulama Nahdlatul Ulama dan masyarakat Indonesia. Di era Globalisasi banyak pemuda yang terpengaruh dengan budaya barat yang tidak sesuai dengan ajaran Ahlussunnah Wal Jama'ah dan Pancasila, maka pemuda Ansor jangan sampai terpengaruh dengan budayabudaya tersebut.

(2). Materi Lapangan, yang terdiri dari : (a). Peraturan Baris-Berbaris (PBB) dilaksanakan pada tanggal 30 Januari 2016 yang dilatih langsung oleh anggota TNI dan POLRI dari Kabupaten Sukoharjo . (b). Caraka malam dan baiat Banser (Barisan Ansor Serbaguna). Kegiatan caraka malam yang dilaksanakan pada malam minggu tanggal 31 Januari 2016 pada tengah malam yang dipimpin oleh beberapa instruktur Banser (Barisan Ansor Serbaguna) dari Pimpinan Cabang Kabupaten Sukoharjo dan Pimpinan Wilayah Provinsi Jawa Tengah. Caraka malam merupakan kegiatan yang disusun pada malam hari yang terdiri dari beberapa pos. Peserta diberi petunjuk untuk melewati rute pos-pos yang sudah disiapkan oleh panitia. Rute yang disediakan pada kegiatan tersebut, yaitu terdiri dari 4 pos yang berjarak kurang lebih $3 \mathrm{~km}$. Rute perjalanan berawal dari pos 1 (berada di Pondok Pesantren Darul Hasan), kemudian menuju pos 2 (berada di sekitar perkampungan), pos 3 (berada di kuburan), dan pos 4 (berada di hutan). Peserta setelah mengikuti kegiatan caraka malam kemudian di baiat menjadi anggota Banser (Barisan Ansor Serbaguna), dengan diiringi doa oleh K.H Sholeh. Baiat Banser (Barisan Ansor Serbaguna) merupakan upacara pengangkatan atau penobatan sekelompok orang menjadi anggota Banser (Barisan Ansor Serbaguna). (c). Bakti sosial. Bakti sosial dilaksanakan oleh peserta Pendidikan dan Latuhan Dasar (Diklatsar) pada tanggal 31 Januari 2016. Kegiatan ini diisi dengan membersihkan lingkungan di sekitar Pondok Pesantren Darul Hasan dan lingkungan Desa Mranggen. Kegiatan tersebut menjadi program penting karena memiliki tujuan untuk meningkatkan kepedulian sosial peserta.

Karakter religius di dalam kegiatan tersebut juga selalu ditekankan melalui kegiatan pengajian sore (sesudah salat Maghrib hingga menjelang salat Isya) dan pagi (sesudah salat Subuh). Di dalam kegiatan tersebut peserta diberi nasehat-nasehat oleh pengasuh Pondok Pesantren Darul Hasan yaitu K.H Sholeh, yang memberi nasehat kepada pemuda agar selalu berdoa kepada Allah SWT, bersholawat kepada nabi Muhammad SAW dan selalu berjuang untuk menegakkan kebenaran. Pemuda merupakan usia yang sangat produktif untuk melakukan maksiat (tindakan yang dilarang agama Islam) sehingga berhati-hatilah dalam bertindak, dan memanfaatkan usia muda sebelum tua dengan beramal sholeh.

Pendidikan dan Latihan Dasar (Diklatsar) yang dilaksanakan Pimpinan Anak 
Pipit Widiatmaka, Agus Pramusinto, dan Kodiran -- Peran Organisasi Kepemudaan Dalam Membangun Karakter Pemuda Dan Implikasinya Terhadap Ketahanan Pribadi Pemuda (Studi Pada Pimpinan Cabang Gerakan Pemuda Ansor Di Kabupaten Sukoharjo Provinsi Jawa Tengah)

Cabang Gerakan Pemuda Ansor di Kecamatan Polokarto yang mendapat rekomendasi dari Pimpinan Cabang Gerakan Pemuda Ansor di Kabupaten Sukoharjo dapat membangun mental dan karakter pemuda, karena di dalam kegiatan tersebut terdapat materi ruangan (teori) dan lapangan (praktik). Melalui Pendidikan dan Latihan Dasar (Diklatsar) Pimpinan Cabang Gerakan Pemuda Ansor di Kabupaten Sukoharjo memiliki anggota Banser (Barisan Ansor Serbaguna) yang mampu menjaga keamanan dan ketertiban di masyarakat khususnya kegiatan pengajian.

\section{Kendala Yang Ada}

Beberapa kendala yang ada dalam membangun karakter pemuda adalah sebagai berikut.

Pertama, keuangan. Pimpinan Cabang Gerakan Pemuda Ansor di Kabupaten Sukoharjo dalam membangun karakter pemuda memiliki beberapa kendala, sehingga kegiatan yang diorientasikan pada pembangunan karakter pemuda sering terbengkalai. Kendala tersebut berdampak pada kualitas kader di organisasi kepemudaan tersebut.

Pimpinan Cabang Gerakan Pemuda Ansor di Kabupaten Sukoharjo memiliki program kerja membangun badan usaha berupa koperasi, namun hingga masa jabatan periode 2013-2017 hampir berakhir belum terealisasi, sehingga dalam hal pendanaan untuk melaksanakan kegiatan menjadi terkendala. Keuangan merupakan salah satu kendala yang menyebabkan kegiatan di Pimpinan Cabang Gerakan Pemuda Ansor di Kabupaten Sukoharjo menjadi terkendala, sehingga ada kegiatan menjadi terhenti, seperti Rijalul Ansor dan Pendidikan Kepemimpinan Dasar (PKD).
Pimpinan Cabang Gerakan Pemuda Ansor di Kabupaten Sukoharjo apabila ingin mengadakan kegiatan selalu terkendala di masalah keuangan, sehingga selalu mencari bantuan ke beberapa pihak dan terkadang iuran anggota. Ketika mengadakan kegiatan yang diorientasikan pada pembangunan karakter pemuda, seperti pengajian akbar dan Pendidikan dan Latihan Dasar (Diklatsar) pengurus selalu kebingungan mencari dana ke beberapa pihak. Misal kegiatan Pendidikan dan Latihan Dasar (Diklatsar) di Kecamatan Polokarto pada tanggal 2931 Januari 2016, pengurus terkendala di permasalahan keuangan, sehingga berusaha untuk mengajukan proposal ke anggota DPR, badan usaha dan tokoh masyarakat.

Anggota DPR menjadi harapan utama untuk mendapatkan bantuan dana, sehingga organisasi tersebut dapat mengadakan kegiatan yang diorientasikan pada pembangunan karkater pemuda. Meskipun mendapat bantuan dari anggota DPR, namun keuangan masih tetap menjadi kendala karena belum mampu mencukupi kebutuhan di dalam kegiatan tersebut, sehingga pengurus mengambil inisiatif untuk iuran, seperti kegiatan Pendidikan dan Latihan Dasar (Diklatsar) yang diadakan di Kecamatan Polokarto pada tangal 29-31 Januari 2016.

Kedua, koordinasi pengurus masih sangat kurang. Koordinasi pengurus menjadi salah satu kendala di dalam Pimpinan Cabang Gerakan Pemuda Ansor di Kabupaten Sukoharjo sehingga mempengaruhi dalam perumusan program kegiatan ke depan di organisasi tersebut (program kerja) khususnya kegiatan yang diorientasikan pada pembangunan karakter pemuda. Organisasi tersebut untuk saat ini tidak memiliki 
program kerja tahunan, sehingga secara langsung berdampak pada terkendalanya dalam mengadakan kegiatan-kegiatan yang diorientasikan pada pembangunan karakter.

Pimpinan Cabang Gerakan Pemuda Ansor di Kabupaten Sukoharjo sebelum kepemimpinan periode 2013-2017 memiliki program pertemuan secara rutin setiap selapan (35 hari) sekali, setiap malam minggu legi. Di dalam pertemuan tersebut terdapat acara pengajian, kemudian dilanjutkan koordinasi antar pengurus, namun kepemimpinan periode 2013-2017 tidak ada koordinasi secara rutin. Bahkan ketika akan mengadakan kegiatan seperti Pendidikan dan Latihan Dasar (Diklatsar) mengumpulkan pengurus sulit, karena memiliki kesibukan masing-masing sehingga banyak kegiatan yang diorientasikan pada pembangunan karakter pemuda menjadi terkendala. Misal ketua panitia Pendidikan dan Latihan Dasar (Diklatsar) yang dilaksanakan di Kecamatan Polokarto pada tanggal 29-31 Januari 2016, mengungkapkan bahwa sebelum mengadakan Pendidikan dan Latihan Dasar (Diklatsar) memiliki kendala yang serius selain keuangan, yaitu koordinasi antar pengurus meskipun kegiatan tersebut pada akhirnya dapat berjalan.

Koordinasi di Pimpinan Cabang Gerakan PemudaAnsor di Kabupaten Sukoharjo menjadi permasalahan yang serius, karena koordinasi menjadi salah satu tolok ukur keberhasilan suatu organisasi dalam membangun karakter anggotanya. Kurangnya koordinasi antar pengurus berdampak pada kurangnya efektif dalam mengadakan suatu kegiatan yang diorientasikan pada pembangunan karkater pemuda.

Ketiga, keaktifan pengurus masih sangat kurang. Kurangnya aktif pengurus dalam berkoordinasi juga menjadi kendala di organisasi tersebut, sehingga kegiatan yang sudah tersusun di dalam program kerja dan Peraturan Organisasi Gerakan Pemuda Ansor menjadi terkendala. Wakil ketua bidang kaderisasi di Pimpinan Cabang Gerakan Pemuda Ansor di Kabupaten Sukoharjo yang dijabat oleh Ma'ruf Budiyanto sudah tidak aktif, hal ini berakibat pada proses kaderisasi yang tidak efektif serta banyak menimbulkan konflik dan kritik, misal kegiatan yang terhenti, yaitu Rijalul Ansor dan Pendidikan Kepemimpinan Dasar (PKD).

Kurang aktifnya pengurus berdampak pada kegiatan di organisasi tersebut menjadi terhenti, seperti Rijalul Ansor, ketika kepemimpinan periode 2009-2013 berjalan rutin setiap malam minggu legi, namun periode 2013-2017 karena tidak ada yang menggerakan sehingga tidak dapat dilaksanakan dengan baik dan rutin. Kegiatan selanjutnya yang menjadi terhenti, yaitu Pendidikan Kepemimpinan Dasar (PKD) baru dilaksanakan satu kali selama kepemimpinan periode 2013-2017, hal itu terjadi karena banyak pengurus yang sibuk dengan pekerjaan sehingga tanggung jawab di organisasi tersebut kurang diperhatikan. Padahal kegiatan tersebut sangat efektif untuk membangun karakter pemuda apabila diimplementasikan dengan baik, karena di dalamnya terdapat materi teori dan praktik.

Berdasarkan observasi di lapangan ketika kegiatan Pendidikan dan Latihan Dasar (Diklatsar) yang diadakan oleh Pimpinan Anak Cabang di Kecamatan Polokarto atas rekomendasi dari Pimpinan Cabang Gerakan Pemuda Ansor di Kabupaten Sukoharjo pada tanggal 29-31 Januari 2016 terlihat ada beberapa pengurus Pimpinan Cabang yang tidak hadir, yaitu Ma'ruf Budiyanto wakil 
Pipit Widiatmaka, Agus Pramusinto, dan Kodiran -- Peran Organisasi Kepemudaan Dalam Membangun Karakter Pemuda Dan Implikasinya Terhadap Ketahanan Pribadi Pemuda (Studi Pada Pimpinan Cabang Gerakan Pemuda Ansor Di Kabupaten Sukoharjo Provinsi Jawa Tengah)

ketua bidang kaderisasi, Ahmad Syafari wakil ketua bidang ekonomi, Sigit Santoso wakil ketua bidang Rijalul Ansor, Eko Jalu Haryanto yang menjabat sebagai departemen pendidikan dan pengkaderan. Fenomena ini menunjukkan bahwa keseriusan para pengurus masih kurang dalam keikutsertaan kegiatan yang diadakan oleh Pimpinan Anak Cabang, sehingga proses pembangunan karakter pemuda menjadi terkendala. Tugas administrasi di dalam Pimpinan Cabang Gerakan Pemuda Ansor di Kabupaten Sukoharjo yang seharusnya dikerjakan oleh sekretaris (Mustofa), namun di organisasi tersebut dikerjakan oleh ketua organisasi (Nuril Huda).

Keempat, terjadi kekosongan jabatan. Wakil ketua yang membidangi Rijalul Ansor selama ini terjadi kekosongan jabatan, karena Sigit Santoso yang menjabat di posisi tersebut sudah tidak aktif dan tempat tinggalnya pindah ke Cirebon karena pekerjaan. Kosongnya jabatan wakil ketua bidang Rijalul Ansor membuat kegiatan tersebut tidak bisa terlaksana dengan baik dan rutin, sehingga pembangunan karakter pemuda melalui kegiatan Rijalul Ansor tidak bisa terlaksana dengan baik. Ketua dan pengurus lainnya sampai saat ini belum memiliki inisiatif untuk menggantikan jabatan yang ditinggalkan oleh Sigit Santosa. Kekosongan jabatan wakil ketua bidang Rijalul Ansor menjadi salah satu penyebab pada kurang seriusnya pengurus lain dalam merencanakan dan melaksanakan kegiatan tersebut, yang sebelum kepemimpinan Nuril Huda (kepemimpinan Khomsun Nur Arif) dapat dilaksanakan secara rutin setiap malam minggu legi.

Berdasarkan observasi pada tanggal 26 Maret 2016 dalam kegiatan Rijalul Ansor di Pimpinan Anak Cabang Gerakan Pemuda
Ansor di zona 2 (Tawangsari, Weru, dan Bulu), Eko selaku ketua Pimpinan Anak Cabang Gerakan Pemuda Ansor di zona 2 mengungkapkan kepada sahabat-sahabat Ansor bahwa kepengurusan di tingkat cabang sedang menggalami kekosongan, karena banyak pengurus yang ingin mengundurkan diri.

Kelima, kepentingan pribadi. Kepentingan pribadi di Pimpinan Cabang Gerakan Pemuda Ansor di Kabupaten Sukoharjo menjadi kendala dalam membangun karakter pemuda, karena kepentingan tersebut menyebabkan terhentinya beberapa kegiatan di organisasi tersebut, yaitu Rijalul Ansor dan Pendidikan Kepemimpinan Dasar (PKD). Kepentingan pribadi yang ada di dalam Pimpinan Cabang Gerakan Pemuda Ansor di Kabupaten Sukoharjo adalah sebagai berikut.

(1). Mencari dukungan dalam pemilu. Pimpinan Cabang Gerakan Pemuda Ansor di Kabupaten Sukoharjo merupakan organisasi kepemudaan yang dimanfaatkan oleh beberapa pengurusnya untuk menjadi pejabat publik, sehingga hal ini berimbas pada kegiatan yang semula berjalan dengan baik dan aktif menjadi tidak aktif dan sering terjadi konflik antar pengurus. Konflik sering terjadi di organisasi tersebut ketika mendekati pemilu untuk memilih anggota DPR. Organisasi tersebut dimanfaatkan oleh beberapa pengurus untuk mencari dukungan agar menjadi anggota DPRD, DPR RI dan wakil Bupati di Kabupaten Sukoharjo.

Pimpinan Cabang Gerakan Pemuda Ansor di Kabupaten Sukoharjo dimanfaatkan oleh beberapa pengurus dan anggotanya untuk mencari dukungan agar dapat menjadi pejabat publik (DPRD, DPR RI, dan wakil 
Bupati). Kepentingan pribadi yang dibawa ke organisasi tersebut berdampak pada kegiatan yang sebelumnya dapat berjalan dengan baik, menjadi terhenti dan juga menimbulkan konflik internal, meskipun tokoh yang memiliki kepentingan pribadi di Pimpinan Cabang Gerakan Pemuda Ansor di Kabupaten Sukoharjo, setelah kepentingannya tercapai tidak melupakan begitu saja atas jasa dari anggota di organisasi tersebut, sehingga setiap ada kegiatan selalu terlibat di dalamnya dengan memberi bantuan, tetapi meskipun organisasi tersebut dipermudah dalam mendapatkan bantuan kegiatan yang berorientasi pada pembangunan karakter tetap belum bisa berjalan kembali dengan baik.

(2). Mencari pekerjaan atau proyek. Beberapa pengurus dan anggota Pimpinan Cabang Gerakan Pemuda Ansor di Kabupaten Sukoharjo memanfaatkan organisasi tersebut untuk mendapatkan pekerjaan dan proyek. Komisioner KPU merupakan jabatan yang diburu oleh beberapa pengurus, terutama ketua Pimpinan Cabang Gerakan Pemuda Ansor di Kabupaten Sukoharjo karena sejak tahun 2004 Komisioner KPUD di Kabupaten Sukoharjo selalu diisi oleh anggota dari organisasi tersebut.

Pada tahun 2004 Khomsun Nur Arif ketika menjadi pengurus di Pimpinan Cabang Gerakan Pemuda Ansor di Kabupaten Sukoharjo terpilih menjadi ketua Komisioner KPUD di Kabupaten Sukoharjo. Pada tahun 2009 ketika beliau menjabat sebagai ketua Pimpinan Cabang Gerakan Pemuda Ansor di Kabupaten Sukoharjo dan juga berstatus sebagai Pegawai Negeri Sipil (PNS) terpilih kembali menjadi ketua Komisioner KPUD di Kabupaten Sukoharjo. Nuril Huda pada tahun 2013 ketika menjabat sebagai ketua Pimpinan
Cabang Gerakan Pemuda Ansor di Kabupaten Sukoharjo dapat terpilih menjadi Komisioner KPUD di Kabupaten Sukoharjo.

Pengurus Pimpinan Cabang Gerakan Pemuda Ansor di Kabupaten Sukoharjo periode 2004-2019, periode 2009-2013 dan periode 2013-2017 selalu terpilih menjadi Komisioner KPUD di Kabupaten Sukoharjo, karena Tim Seleksi Komisioner KPUD di Kabupaten Sukoharjo dalam melakukan seleksi dengan wawancara kurang transparan.

Pilkada di Kabupaten Sukoharjo yang dilaksanakan pada tanggal 9 Desember 2015, dimanfaatkan oleh salah satu Komisioner KPUD yang juga merupakan ketua Pimpinan Cabang Gerakan Pemuda Ansor di Kabupaten Sukoharjo dengan memilih sebagian besar dari anggota Pimpinan Anak Cabang dan Pimpinan Cabang Gerakan Pemuda Ansor di Kabupaten Sukoharjo untuk menjadi Panitia Pemilihan Kecamatan (PPK). Beberapa anggota yang menjadi Panitia Pemilihan Kecamatan (PPK) pada pilkada di Kabupaten Sukoharjo tahun 2015, tidak terlepas dari peran ketua Pimpinan Cabang Gerakan Pemuda Ansor di Kabupaten Sukoharjo yang menjabat sebagai Komisioner KPUD di Kabupaten Sukoharjo, karena yang berhak menentukan terpilihnya sebagai Panitia Pemilihan Kecamatan (PPK) adalah Komisioner KPUD.

\section{Karakter Pemuda Pimpinan Cabang Gerakan Pemuda Ansor di Kabupaten Sukoharjo}

Pembangunan karakter pemuda di organisasi kepemudaan Pimpinan Gerakan Pemuda Ansor di Kabupaten Sukoharjo pada dasarnya melalui tiga kegiatan, yaitu Rijalul Ansor, Pendidikan Kepemimpinan Dasar (PKD), serta Pendidikan dan Latihan 
Pipit Widiatmaka, Agus Pramusinto, dan Kodiran -- Peran Organisasi Kepemudaan Dalam Membangun Karakter Pemuda Dan Implikasinya Terhadap Ketahanan Pribadi Pemuda (Studi Pada Pimpinan Cabang Gerakan Pemuda Ansor Di Kabupaten Sukoharjo Provinsi Jawa Tengah)

Dasar (Diklatsar), namun yang hanya dapat diimplementasikan adalah Pendidikan dan Latihan Dasar (Diklatsar). Fenomena tersebut bisa terjadi karena ada beberapa kendala, sehingga kegiatan Rijalul Ansor dan Pendidikan Kepemimpinan Dasar (PKD) tidak bisa berjalan dengan efektif dan berkelanjutan. Padahal pendidikan karakter yang bertujuan untuk membangun karakter pemuda harus berjalan secara berkelanjutan dan membutuhkan suatu strategi atau metode yang efektif, sehingga karakter pemuda dapat terbangun.

Pendidikan karakter yang diimplementasikan oleh Pimpinan Cabang Gerakan Pemuda Ansor di Kabupaten Sukoharjo belum mampu membangun karakter pemuda secara maksimal. Pimpinan Cabang Gerakan Pemuda Ansor di Kabupaten Sukoharjo belum bisa membangun karakterkarakter yang sudah dijelaskan oleh Ambarita di landasarn teori secara menyeluruh. Karakter yang dapat dibangun melalui kegiatan Pendidikan dan Latihan Dasar (Diklatsar), yaitu religius, tanggung jawab, disiplin, mandiri, kejujuran, amanah, peduli antar sesama, kerja sama, percaya diri, kreatif, pantang menyerah, kepemimpinan, toleransi, dan cinta tanah air. Karakter yang belum bisa dibagun melalui kegiatan-kegiatan di Pimpinan Cabang Gerakan Pemuda Ansor di Kabupaten Sukoharjo khususnya Pendidikan dan Latihan Dasar (Diklatsar), yaitu rasa hormat, sopan santun, kasih sayang, adil, dan rendah hati.

\section{Implikasinya Terhadap Ketahanan Pribadi Pemuda}

Beberapa implikasi peran Pimpinan Cabang Gerakan Pemuda Ansor dalam membangun ketahanan pribadi pemuda dapat dijelaskan sebagai berikut.

Pertama, rasa percaya diri dan berpegang pada prinsip. Peran Pimpinan Cabang Gerakan Pemuda Ansor di Kabupaten Sukoharjo dalam membangun karakter pemuda belum berimplikasi secara maksimal terhadap ketahanan pribadi pemuda di organisasi tersebut, khususnya kepribadian percaya diri dan berpegang pada prinsip, karena kegiatan Rijalul Ansor dan Pendidikan Kepemimpinan Dasar (PKD) belum berjalan dengan baik dan efektif. Kegiatan yang dapat membangun kepribadian percaya diri dan berpegang teguh pada prinsip hanyalah Pendidikan dan Latihan Dasar (Diklatsar), karena kegiatan yang berjalan dengan efektif dan di dalam kegiatan tersebut terdapat materi teori (ruangan) dan praktik (lapangan). Rijalul Ansor yang awalnya diadakan secara rutin setiap malam minggu legi sudah tidak dilaksanakan, sedangkan Pendidikan Kepemimpinan Dasar (PKD) selama kepemimpinan periode 2013-2017 baru 1 (satu) kali dilaksanakan. Pada dasarnya kedua kegiatan tersebut, di era kepemimpinan periode 2009-2013 sangat efektif untuk membangun ketahanan pribadi pemuda khususnya percaya diri dan berpegang teguh pada prinsip, karena dapat berjalan dengan efektif.

Kepercayaan diri pemuda di Pimpinan Cabang Gerakan Pemuda Ansor di Kabupaten Sukoharjo yang dibangun melalui kegiatan Pendidikan dan Latihan Dasar (Diklatsar) melalui materi ruangan, yaitu melalui materi Ahlussunnah Wal Jama'ah dan pendidikan bela negara. Ajaran tersebut dapat menumbuhkan rasa kepercayaan diri anggota dengan meyakini dan berpegang teguh pada ajaran empat mazhab, yaitu Syafi'i, Hanafi, Maliki, dan 
Hambali serta memiliki jiwa nasionalisme dan patriotisme yang dibangun melalui pendidikan bela negara. Di sisi lain, TNI dan POLRI juga terlibat di dalam kegiatan tersebut dan memberi materi ruangan (pendidikan bela negara) dan materi lapangan (PBB), sehingga tidak dapat dipungkiri apabila anggota Banser (Barisan Ansor Serbaguna) memiliki ketahanan pribadi yang tangguh khususnya kepercayaan diri dan berpegang teguh pada prinsip.

Ahlussunnah Wal Jama'ah merupakan ajaran yang selalu ditekankan di organisasi tersebut, selain itu sikap dan perilaku untuk selalu membela tanah air juga menjadi prinsip yang dipegang di dalam organisasi tersebut. Pemuda di Pimpinan Cabang Gerakan Pemuda Ansor di Kabupaten Sukoharjo yang pernah mengikuti kegiatan Pendidikan dan Latihan Dasar (Diklatsar) untuk menjadi Banser (Barisan Ansor Serbaguna), pada dasarnya memiliki kepercayaan diri dan berpegang pada prinsip, namun terkadang ada beberapa pemuda yang terlalu fanatik dan belum bisa mengendalikan emosinya, ketika berdiskusi dengan temannya yang memiliki perbedaan faham yang diyakininya.

Di Kabupaten Sukoharjo banyak berkembang faham yang terkadang berbenturan antara satu dengan yang lainnya dan juga ada faham yang berbenturan dengan ajaran Ahlussunnah Wal Jama'ah. Misal yasinan dan tahlilan yang merupakan ajaran dari Gerakan Pemuda Ansor, ditentang oleh pemuda lain yang tergabung di dalam organisasi Majelis Tafsir Al Qur'an (MTA) yang mengatakan bahwa yasinan dan tahlilan haram sebab tidak pernah diajarkan oleh nabi Muhammad SAW. Perbedaan tersebut terkadang menjadi konflik ketika pemuda dari Gerakan Pemuda Ansor berdiskusi dengan pemuda dari Majelis Tafsir Al Qur'an (MTA).
Berdasarkan observasi di dalam kegiatan Pendidikan dan Latihan Dasar (Diklatsar) yang dilaksanakan di Pondok Pesantren Darus Hasan, Kecamatan Polokarto pada tanggal 29-31 Januari 2016, ketika peserta mengikuti kegiatan caraka malam yang dilaksanakan pukul 00.00 (malam), peserta diberi motivasi oleh instrukturnya bahwa anggota Banser (Barisan Ansor Serbaguna) harus mampu menyesuikan diri terhadap lingkungan dan memiliki keyakinan bahwa setiap masalah dan rintangan dapat diselesaikan dengan doa dan usaha. Keyakinan tersebut dipegang oleh peserta sehingga memiliki kepercayaan diri bisa melewati rute yang melewati kuburan, hutan, dan pemukiman penduduk dan semua peserta Pendidikan dan Latihan Dasar (Diklatsar) mampu melewati rute yang sudah disiapkan oleh panitia tersebut.

Pemuda yang memiliki kepribadian percaya diri dan berpegang teguh pada prinsip dapat dibangun melalui beberapa kegiatan yang di dalamnya terdapat materi teori dan materi praktik, kegiatan tersebut harus dapat dilaksanakan secara serius dan berkelanjutan. Pimpinan Cabang Gerakan pemuda Ansor di Kabupaten Sukoharjo pada dasarnya memiliki beberapa kegiatan yang dapat membangun kepercayaan diri dan berpegang teguh pada prinsip, namun yang berjalan dengan baik dan efektif hanya Pendidikan dan Latihan Dasar (Diklatsar), sehingga pemuda di organisasi tersebut yang memiliki kepercayaan diri dan berpegang teguh pada prinsip hanya kader inti atau sering disebut dengan Banser (Barisan Ansor Serbaguna).

Kedua, jiwa dinamis, kreatif dan pantang menyerah. Pimpinan Cabang Gerakan Pemuda Ansor di Kabupaten Sukoharjo memiliki kegiatan yang dapat menumbuhkan 
Pipit Widiatmaka, Agus Pramusinto, dan Kodiran -- Peran Organisasi Kepemudaan Dalam Membangun Karakter Pemuda Dan Implikasinya Terhadap Ketahanan Pribadi Pemuda (Studi Pada Pimpinan Cabang Gerakan Pemuda Ansor Di Kabupaten Sukoharjo Provinsi Jawa Tengah)

kepribadian yang dinamis untuk melakukan perubahan, memiliki kreativitas, dan pantang menyerah, yaitu Pendidikan dan Latihan Dasar (Diklatsar), meskipun masih ada beberapa kegiatan yang lain dapat menumbuhkan kepribadian tersebut, namun belum bisa dilaksanakan dengan baik dan efektif yaitu Rijalul Ansor dan Pendidikan Kepemimpinan Dasar (PKD). Hal tersebut bisa terjadi karena ada beberapa kendala, yaitu koordinasi pengurus yang masih kurang dan adanya kepentingan pribadi di dalam organisasi tersebut.

Pendidikan dan Latihan Dasar (Diklatsar) dapat berimplikasi pada ketahanan pribadi pemuda khususnya kepribadian yang dinamis untuk melakukan perubahan, memiliki kreativitas, dan pantang menyerah. Anggota yang mengikuti kegiatan Pendidikan dan Latihan Dasar (Diklatsar) diharapkan dapat menjadi kader inti di organisasi tersebut atau sering disebut Banser (Barisan Ansor Serbaguna) mengakui dan merasakan sendiri bahwa kegiatan tersebut dapat menumbuhkan kreativitas dan pantang menyerah

Implikasi dari Pendidikan dan Latihan Dasar (Diklatsar) juga dirasakan oleh anggota lain yang mengikuti kegiatan tersebut, terutama pantang menyerah dalam berdakwah agar masyarakat dapat menaati perintah agama dan menjauhi segala larangannya. Di Kabupaten Sukoharjo selama ini banyak berkembang paham-paham agama Islam yang berpotensi pada konflik, misal ada salah satu organisasi yang menyatakan bahwa ada beberapa ajaran Gerakan Pemuda Ansor dikatakan syirik, seperti tahlilan dan yasinan. Fenomena tersebut menuntut anggota Pimpinan Cabang Gerakan Pemuda Ansor di Kabupaten Sukoharjo untuk pantang menyerah mempertahankan ajaran tersebut, meskipun selalu mendapat tekanan dari orang lain atau organisasi lain.

Berdasarkan observasi di dalam kegiatan Pendidikan dan Latihan Dasar (Diklatsar) terdapat beberapa kegiatan yang dapat menumbuhkan kepribadian yang pantang menyerah dan kreativitas pemuda. Kegiatan itu ialah caraka malam dan out bond, yang menuntut peserta agar menjadi individu yang pantang menyerah untuk melewati rintangan-rintangan yang sudah disipkan oleh panitia, selain itu peserta juga dituntut untuk mengeluarkan kreativitasnya dengan menggunakan strategi bagaimana agar dapat melewati rintangan atau permasalahan yang ada.

Pemuda di Pimpinan Cabang Gerakan Pemuda Ansor di Kabupaten Sukoharjo yang memiliki ketahanan pribadi khususnya kepribadian yang dinamis untuk melakukan perubahan, memiliki kreativitas, dan pantang menyerah pada dasarnya hanya kader inti atau sering disebut dengan Banser (Barisan Ansor Serbaguna).

Ketiga, mandiri dan mendambakan kebersamaan. Pimpinan Cabang Gerakan Pemuda Ansor di Kabupaten Sukoharjo memiliki kegiatan yang dapat membangun karakter pemuda dan berimplikasi pada kemandirian pemuda serta selalu menjunjung kebersamaan dalam perbedaan di lingkungan sekitarnya, yaitu Pendidikan dan Latihan Dasar. Meskipun ada kegiatan lain yang dapat berimplikasi pada kemandirian dan jiwa kebersamaan, yaitu Rijalul Ansor dan Pendidkan Kepemimpinan Dasar (PKD), namun kegiatan tersebut terkendala sehingga tidak dapat berjalan dengan baik dan efektif sehingga tidak seluruh anggota Pimpinan Cabang Gerakan Pemuda Ansor 
di Kabupaten Sukoharjo memiliki ketahanan pribadi khususnya kemandirian dan jiwa kebersamaan.

Anggota yang pernah mengikuti kegiatan di Pimpinan Cabang Gerakan Pemuda Ansor di Kabupaten Sukoharjo khususnya kegiatan Pendidikan dan Latihan Dasar (Diklatsar) dengan yang belum pernah mengikuti kegiatan tersebut memiliki perbedaan dalam bersikap dan berperilaku, terutama kemandirian dan kebersamaannya. Kegiatan Pendidikan dan Latihan Dasar (Diklatsar) dapat mempengaruhi kepribadian pemuda, sehingga anggota yang sudah pernah mengikuti kegiatan tersebut memiliki perbedaan dalam bersikap dan berperilaku dengan anggota yang belum pernah mengikuti Pendidikan dan Latihan Dasar (Diklatsar).

Berdasarkan observasi di lapangan ketika kegiatan Pendidikan dan Latihan Dasar (Diklatsar) berlangsung, terdapat kegiatan yang dapat menumbuhkan kemandirian dan jiwa kebersamaan, yaitu caraka malam. Kegiatan ini dilaksanakan pada pukul 00.00 WIB (malam) dan seluruh peserta yang mengikuti kegiatan ini dibagi menjadi 8 kelompok. Setiap kelompok diberangkatkan secara berurutan dan harus berangkat sendiri dengan waktu yang berbeda. Apabila ada peserta yang belum sampai ke pos akhir dan melebihi waktu yang sudah ditentukan oleh panitia, maka yang bertanggung jawab adalah satu kelompok sehingga seluruh anggota kelompok harus mencari peserta yang belum sampai ke pos akhir.

Kegiatan caraka malam pada dasarnya bertujuan untuk menumbuhkan jiwa kemandirian dan kebersamaan pemuda, karena awalnya berkelompok kemudian diberangkatkan sendiri dan menuntut untuk berusaha sendiri semaksimal mungkin untuk menemukan jalan hingga pos akhir. Pada akhir kegiatan ini peserta dituntut untuk mengeluarkan jiwa kebersamaan, karena yang bertanggung jawab tidak secara individu, namun satu kelompok. Metode ini dalam implementasinya sangat efektif untuk membangun kemandirian dan jiwa kebersamaan pemuda.

Pemuda di Pimpinan Cabang Gerakan Pemuda Ansor di Kabupaten Sukoharjo yang memiliki ketahanan pribadi hanya kader intinya atau sering disebut Banser (Barisan Ansor Serbaguna), karena kegiatan yang lainnya seperti Rijalul Ansor dan Pendidikan Kepemimpinan Dasar (PKD) tidak dapat diimplementasikan dengan baik dan efektif.

\section{SIMPULAN}

Berdasar penjelasan tersebut di atas dapat ditarik simpulan sebagai berikut.

Pertama, Pimpinan Cabang Gerakan Pemuda Ansor di Kabupaten Sukoharjo memiliki peran dalam membangun karkater pemuda, meskipun masih sangat kurang maksimal karena banyak memiliki kendala salah satunya koordinasi. Ketua Pimpinan Cabang Gerakan Pemuda Ansor di Kabupaten Sukoharjo pada periode 2013-2017 pada dasarnya belum memiliki sikap kepemimpinan yang bagus, karena belum mampu menyusun program kerja dengan baik, meskipun masih ada beberapa kegiatan yang diorientasikan pada pembangunan karakter pemuda dapat berjalan. Di sisi lain, beberapa pengurus di organisasi tersebut masih kurang memperhatikan tanggung jawabnya sebagai seorang pengurus organisasi, karena banyak tugas dan kewajibannya ditinggalkan sehingga kegiatan yang dapat berjalan hanya Pendidikan dan Pelatihan Dasar (Diklatsar). 
Pipit Widiatmaka, Agus Pramusinto, dan Kodiran -- Peran Organisasi Kepemudaan Dalam Membangun Karakter Pemuda Dan Implikasinya Terhadap Ketahanan Pribadi Pemuda (Studi Pada Pimpinan Cabang Gerakan Pemuda Ansor Di Kabupaten Sukoharjo Provinsi Jawa Tengah)

Kedua, karakter yang dapat dibangun melalui Pendidikan dan Latihan Dasar (Diklatsar) yaitu religius, tanggung jawab, disiplin, mandiri, peduli antar sesama, kerja sama, percaya diri, kreatif, pantang menyerah, kepemimpinan, toleransi, dan cinta tanah air, sedangkan karakter yang belum bisa dibangun, yaitu rasa hormat, sopan santun, kasih sayang, adil, kejujuran, amanah, dan rendah hati.

Ketiga, Pimpinan Cabang Gerakan Pemuda Ansor di Kabupaten Sukoharjo hanya memiliki 1 (satu) kegiatan yang dapat berimplikasi pada ketahanan pribadi pemuda, yaitu Pendidikan dan Latihan Dasar (Diklatsar). Kegiatan tersebut dapat membangun kepribadian yang mandiri, kebersamaan, percaya diri, berpegang teguh pada prinsip, dinamis, kreatif dan pantang menyerah. Pada dasarnya tidak semua pemuda yang tergabung di dalam Pimpinan Cabang Gerakan Pemuda Ansor di Kabupaten Sukoharjo memiliki ketahanan pribadi, namun hanya kader intinya saja atau sering disebut Banser (Barisan Ansor Serbaguna) yang memiliki ketahanan pribadi, karena sudah pernah mengikuti Pendidikan dan Latihan Dasar (Diklatsar) dan siap untuk menjaga keamanan dan ketertiban di masyarakat.

\section{DAFTAR PUSTAKA}

Ambarita, Biner. 2013. "Profesionalisme, Esensi Kepemimpinan, dan Manajemen Organisasi”. Jurnal Generasi Kampus. Volume 6, Nomor 2, September 2013. Hal. 1-16.

Astuti, Siti Irene. 2010. "Pendekatan Holistik dan Kotekstual dalam Mengatasi Krisis Karakter di Indonesia”. Jurnal Cakrawala Pendidikan. Edisi Khusus Dies Natalis UNY, Mei 2010. Hal. 41-58.
Cahyono, Guntur. 2015. "Opini: Pemuda Agen Perdamaian". http://joglosemar. com/2015/04/opini-pemuda-agenperdamaian.html. 27 April 2015, diakses pada tanggal 5 Oktober 2015.

Dewanta, Pandu dan Syaifullah, Cavchay. 2008. Rekontruksi Pemuda. Jakarta: Kementerian Pemuda dan Olahraga.

Dradjad, Sjamsul. 2015. "BNN: Pemuda dan Narkoba, Lingkaran Setan yang Mengerikan".http://kriminalitas.com/bnnpemuda-dan-narkobalingkaran -setanyang-mengerikan. 24 Februari 2015 , diakses pada tanggal 17 Oktober 2015.

Fadeli, Soeleiman dan Subhan Muhammad, 2010, Antologi NU Buku I: Sejarah, Istilah, Amaliah, dan Uswah. Surabaya: Khalista.

Fuad, Munawar. 2010. Membangkitkan Ruh Ansor: Spirit Lanjutkan Pengabdian Perjalanan Seorang Kader Grassroot. Jakarta: MF GP Ansor.

Kholil, Akhmad. 2014. "Pria Tanpa Identitas Tewas Dianiaya Tiga Pemuda". http://m. nasional.rimanews.com/, 31 Oktober 2014, diakses pada tanggal 17 Oktober 2015.

Majid, Abdul dan Dian Andayani. 2012. Pendidikan Karakter Perspektif Islam. Bandung: PT Remaja Rosdakarya.

Muslich, Masnur. 2011. Pendidikan Karakter Menjawab Tantangan Krisis Multidimensional. Jakarta: Bumi Aksara.

Primartantyo, Ukky. 2012. "SBY Dijadwalkan Hadir di Milad GP Ansor". http://www. tempo.co/read/news/2012/07/13. 13 Juli 2012, diakses pada tanggal 10 April 2015

Ridho. 2015. "Prof. Irwan Prayitno: Banyak Organisasi Pemuda Hidup Segan Mati 
Tak Mau”. http://www.sumbarpost.com/ berita-2216-html. 14 April 2015, diakses pada tanggal 5 Oktober 2015

Soedarsono, Soemarno. 1997. Ketahanan Pribadi dan Ketahanan Keluarga Sebagai Tumpuan Ketahanan Nasional. Jakarta: PT Intermasa

Soekanto, Soerjono. 2009. Sosiologi. CV. Rajawali: Jakarta

Suyadi. 2013. Strategi Pembelajaran Pendidikan Karakter. Bandung: PT Remaja Rosdakarya.

Tilaar, H,A.R. 1991. Tinjauan Pedagogis Mengenai Pemuda: Suatu Pendekatan Ekosentris. Pemuda dan Perubahan Sosial. Jakarta: LP3ES
Wibowo, Kurniawan. 2015. Bubarkan Pemuda Nongkrong, Polisi Sukoharjo Kena Tembak. http://joglosemar.co/2015/01/ bubarkan-pemuda-nongkrong-polisisukoharjo-kena-tembak.html. 25 Januari 2015, diakses pada tanggal 17 Oktober 2015

\section{Peraturan Perundangan}

Undang-Undang Republik Indonesia Nomor 40 Tahun 2009 tentang Kepemudaan (Lembaran Negara Republik Indonesia Nomor 148 Tahun 2009, Tambahan Lembaran Negara Republik Indonesia Nomor 5067). 